\title{
2019 Novel Coronavirus Disease Outbreak and Molecular Genetic Characteristics of Severe Acute Respiratory Syndrome-Coronavirus -2
}

\section{Yong Seok Jeong}

\author{
Department of Biology, College of Sciences, Kyung Hee University, Seoul, Korea
}

\section{Corresponding}

Yong Seok Jeong

Department of Biology, College of Sciences,

Kyung Hee University, Seoul, Korea

Phone : +82-2-961-0829

Fax : +82-2-961-0244

E-mail : ysjeong@khu.ac.kr

Received : March 02, 2020

Revised : March 09, 2020

Accepted : March 12, 2020

No potential conflict of interest relevant to this article was reported.

Copyright (C) 2020 Journal of Bacteriology and Virology

(C)This is an Open Access article distributed under the terms of the Creative Commons Attribution Non-Commercial License (http://creativecommons.org/ license/by-nc/3.0/).
The 2019 novel coronavirus disease (COVID-19) outbreaks that emerged in Wuhan city, Hubei province, have led to a formidable number of confirmed cases that resulted in $>5,700$ deaths globally, including 143 countries in all 6 continents. The World Health Organization declared a Public Health Emergency of International Concern with a very high level of global risk assessment. Severe acute respiratory syndrome (SARS)-coronavirus-2 (SARS-CoV-2), the agent of COVID-19, has $>79 \%$ nucleotide sequence homology to SARS-CoV; therefore, both belong to the genus betacoronavirus and subgenus sarbecovirus. The S1 domains of the two appeared to share the cellular receptor ACE2, but revealed a much higher S1-ACE2 binding affinity. As seen in many other human coronaviruses, SARS-CoV-2 also shows respiratory infection, but the basic reproductive number $\left(R_{0}\right)$ in transmission and the clinical latency are quite dissimilar from those of SARS- or MERS-CoVs. Many scientists infer that the time point of cross-barrier transfer from bats to mediate animals or to humans should be a rather recent event based on the full-length genome analyses obtained from the very first patients. Copy-choice polymerization, which often leads to a significant genome recombination rate in most coronaviruses, predicts the continued emergence of novel coronaviruses.

Key Words: COVID-19, SARS-CoV-2, human coronaviruses, genome recombination

\section{INTRODUCTION}

코로나바이러스는 최근 일반인들이 알게 된 것과는 달리 이미 1960년대 중반에 포유 류 및 조류 가축과 사람에게 호흡기 및 소화기 질병을 일으키는 병원체로 확인된 상당 히 큰 집단을 이루고 있는 RNA 바이러스이다 (1). 코로나바이러스 감염숙주로는 특히 큰 경제적 손실을 가져오는 돼지, 소, 말, 토끼, 닭, 칠면조 등의 가축과 개, 고양이 등의 반려동물, 그리고 야생의 다양한 박쥐, 설치류에 이어 사람까지 그 범위가 매우 넓다 (2). 특정 바이러스의 발생과 진화 역사가 숙주범위와 반드시 일치하는 것은 아 니지만 조류와 포유류에 모두 걸쳐 감염한다는 사실은 코로나바이러스의 역사도 상당 한 기간으로 이어 왔을 가능성이 적지 않다.

코로나바이러스의 구조와 생활사

코로나바이러스의 외형은 지질이중층 피막(envelop)으로 둘러싸인 직경 118 136 nm 의 비정형 구형이다. 바이러스 수용체로서 부착과 막융합을 주도하는 $\mathrm{S}$ 단백질, 지질 피막의 안쪽으로 뻗어 모양을 잡아주는 다량의 $\mathrm{M}$ 단백질, 그리고 바이러스 종류에 따라 감염성에 가변적 영향을 미치는 $\mathrm{E}$ 단백질 등의 주요 구조단백질이 피막에 연합되 
어 있는 전형적인 피막형(enveloped) 바이러스에 속한다 (1). 바깥쪽으로 두드러지게 뻗어 나온 S 단백질이 마치 왕관을 연상케 하는데서 이 바이러스의 이름도 유래한다. 바이러스의 유전체는 바이러스가 코딩하는 N 단백질로 빈틈없이 둘러싸인 약 26 32 $\mathrm{kb}$ (1 kb는 염기 1000개)의 단일가닥 RNA 한 분자이며 탈외피 후 세포질의 리보솜과 결합해 곧 바로 복제/전사효소복합체 (RTP) 단백질을 번역해낼 수 있는 양극성 $(+)$ 이다 $(2,3)$. 유전자들은 크게 14 개 정도로 구별되지만 RTP는 실제 16개 정도의 작은 단백질들이 합쳐진 것이므로 세분하면 그 수는 더 많아진다.

바이러스의 일반적 속성에 따라 코로나바이러스도 숙주의 특정 장기와 조직을 이루는 특정 세포를 만나 그 세포의 세포막 단백질 중 하나에 부착하면서 숙주세포 안쪽으로 진입을 시도한다. 이때 코로나바이러스 S 단백질과 만나 진입을 매개하는 세포 수용체의 분자적 구조는 바이러스 수용체 구조와 가능한 높은 상보성을 지녀야 안정된 흡착상태를 형성하고 이는 결국 이 바이러스 감염에 대한 감수성을 결정하는 핵심 요인이 된다 (1). 즉 같은 코로나바이러스라 하더라도 일반감기, 사스, 메르스, 코로나19의 병원체가 나름대로 차별적인 수용체 간 상호작용을 나타내는데, 세포의 어떤 수용체와 만나는가에 따라 감염이 시작되거나 확산되는 경로가 달라지며 이러한 차이에 따라 숙주의 면역체계가 대응하는 방법과 수위가 달라지고 이는 결국 질병의 발생과 진행의 차이로 귀결되기 때문에 주어진 바이러스와 숙주 세포의 수용체에 깊은 관심을 기울이는 것이 합리적이다 $(2,4)$. 이러한 상호작용을 분자 수준에서 밝혀내고 동시에 이들 수용체 간의 만남을 저해할 수 있다면 감염의 첫 단계를 차단하게 되므로 유용한 항바이러스제 개발에서도 특히 중요한 부분일 수밖에 없다.

코로나바이러스는 수용체 상호작용을 매개로 바이러스의 피막과 세포막이 융합을 일으키고 그 결과 바이러스 유전체와 단백질 일부가 세포질 내에 노출된다. 이 융합과정은 세포막에서 이뤄질 수도 있지만 일단 세포막에 둘러싸인 막소낭 형태로 삼켜진 다음에 이뤄질 확률이 높다. 세포질에 노출된 바이러스의 단일가닥 $(+)$ RNA 유전체는 곧 바로 세포의 리보솜과 만나 이후 복제 과정에 필요한 바이러스 RTP를 합성하면서 본격적인 자손 유전체의 복제와 바이러스 유전자 발현을 시작한다. 입자에서 풀어 헤친 유전체를 복사하면 반대 극성인 (-)RNA가 생산되는데 이를 주형(anti-genomic RNA template)으로 써서 (+)RNA 유전체 및 각 유전자의 발현에 사용될 sgRNA (subgenomic mRNA)들을 전사한다 (1-3). 이렇게 생산된 sgRNA들은 유전체 RNA와 5' 말단 및 $3^{\prime}$ 말단의 리더(L)서열과 UTR은 같고 길이는 차례로 줄어드는 형태로서 mRNA 둥지조(nested set)라 부른다. 이와 같은 sgRNA들로부터 앞서 새로 복제한 $(+) R N A$ 유전체를 감싸 입자를 구성하게 될 구조단백질들 $(S, E, M, N)$ 과 여타 기능에 필요한 비구조단백질 $(2 \mathrm{a}, 3 \mathrm{a}, 3 \mathrm{~b}, 6,7 \mathrm{a}, 7 \mathrm{~b}, 8 \mathrm{a}, 8 \mathrm{~b}, 9 \mathrm{~b})$ 을 합성하여 감염력이 완비된 자손 바이러스 입자들을 다량 생성하는 것이다 $(1,2)$. 이 과정에서 주목되는 부분은 코로나바이러스의 독특한 복제/전사 전략인데 주형이 되는 가닥을 복사해나가던 효소-복사물 복합체가 일정 부분 복사를 진행하다가 종종 주형에서 떨어져 나가 다시금 주형에 들러붙어 복사를 계속한다는 점 이다. 만약 효소복합체가 중간에 이탈했던 주형과 다시 결합한 주형이 서로 다른 종류의 주형일 경우에는 마치 주형가닥 2개가 각각 잘려 새로 짝지은 것과 같은 재조합 유전체가 생성되는데 이를 '주형-선택(copy-choice 또는 template switching)' 기전 이라고 한다. 실제 현재까지 발견된 여러 코로나바이러스 종류에서는 이와 같은 재조합의 오랜 흔적이 쉽게 확인된다 (3) (Fig. 1)

유전자 재조합 현상은 MHV (mouse hepatitis virus)와 TGEV (transmissible gastroenteritis virus)와 같이 동물 코로나바이러스 에서 잘 알려져 있으며 사람의 코로나바이러스에서도 OC43, NL63, HKU1, SARS-CoV (severe acute respiratory syndromecoronavirus), 그리고 MERS-CoV (Middle East respiratory syndrome-coronavirus) 등에서 재조합 현상이 보고된 바 있다 (1). OC43, NL63, HKU1 등은 주로 종내 (intraspecies) 재조합이 나타나고 있지만 SARS-CoV의 경우에는 알파 및 베타코로나 바이러스 속이 모두 관여한 복합적인 재조합 흔적을 지니고 있다. 일례로 사향고양이에서 채취한 SARS-CoV CV7에서는 PEDV (porcine epidemic diarrhea virus), TGEV, BCV (bovine coronavirus), 229E, MHV 및 IBV (infectious bronchitis virus) 유래 염기서열들이 모두 발견된다 (3). 코로나바이러스의 유전자 재조합 발생 위치는 무작위하게 나타나며 숙주범위를 결정하는 $\mathrm{S}$ 유전자 영역도 포함되는 것으로 나타났다. 


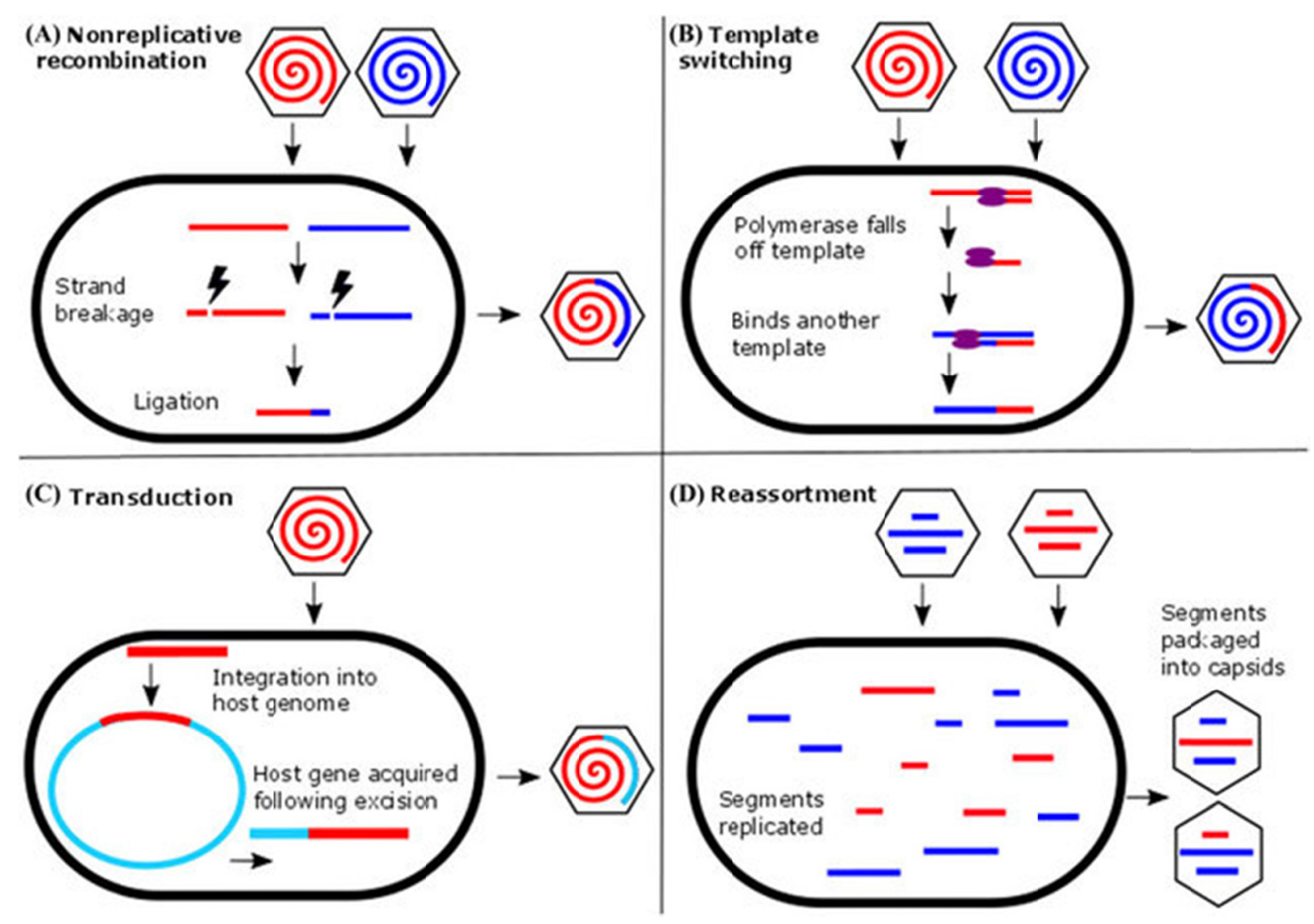

Fig. 1. Major mechanisms of virus genetic recombination. (A) In nonreplicative recombination, nucleic acid strand breakage and repair permit the recombination of genetic material from different sources into the same viral genome. (B) In replicative recombination or template switching, a polymerase molecule changes template during the process of replicating a nucleic acid strand. If the templates are derived from different sources, then novel genetic material can be introduced into the virus genome. (C) During the process of virus integration and excision from a host genome, viruses can acquire genetic material from the host. (D) Reassortment occurs following coinfection of a host cell by multiple segmented viruses. Replicated genome segments are packaged into procapsids irrespective of the parent of origin. (Adapted from ref. (20), Dennehy J. Evolutionary ecology of virus emergence: Virus emergence. Ann N Y Acad Sci 2016 1389(1) DOI:10.1111/nyas.13304)

지금껏 발견된 RNA바이러스 중 가장 긴 유전체를 가졌음에도 불구하고 코로나바이러스의 돌연변이 발생률은 약 $10^{-4}$ (substitution/site/year) 정도로 대부분의 RNA 바이러스와 비슷하거나 약간 높은 수준이다 (3). 이와 같은 복제 정확도는 일정 부분 코로나바이러스 RTP의 보기 드문 복제오류 교정활성에 기인할 것으로 판단되며 이는 유전적 안정성과 오류 임계 (error threshold) 회피에도 도움이 될뿐더러 유전자 재배치의 가소성에도 기여한다. 결국 코로나바이러스의 다양한 변종 생성을 동반한 진화는 주로 이 독특한 복제/전사 전략에 기인할 가능성이 높다. 오늘날 자연숙주 및 매개동물을 포함한 다양한 숙주에서 나름의 감염을 일으키는 코로나바이러스 종들이 종간 장벽을 넘는 시나리오는 두 가지로 정리 된다: 한 가지는 자연숙주에서 지속감염 상태를 유지하고 있는 바이러스 유사종(quasi-species)들 중에서 우연한 재조합을 거쳐 사람 또는 매개동물 전파가 가능한 수용 체를 획득한 변이주가 생성될 가능성, 두 번째는 점돌연변이의 축적으로 숙주범위에 변화가 생긴 변종이 우연한 기회에 사람 으로 직접 넘어가거나 매개동물로 전파된 다음 그 숙주종에서 적응적 진화를 겪고 사람으로 넘어갈 가능성이다 (5). 이러한 가능성들은 각각 별도의 경로로 작동할 수 있을 것이나 한편으로는 조합적으로 작용할 가능성이 적지 않으며 이런 점에서 코로나바이러스가 종간 장벽을 넘어 전파될 확률은 상시적 실재로 여겨진다. 


\section{SARS-CoV-2의 출현과 계통 분석}

2020년 2월 7일 국제바이러스계통분류위원회(ICTV)의 코로나바이러스 연구그룹(CSG)은 신종 코로나바이러스의 이름을 'SARS-CoV-2'로 제안했다 (6). 2월 12일 국제보건기구(WHO)는 그간 임시로 사용되었던 신종 폐렴 병원체인 '2019-nCoV'에 의한 병명을 'COVID-19 (COrona V/rus Disease-19)'로 결정했음을 공표하였고 (7) 같은 날 우리나라 보건당국이 공식명칭으로 채택한 신종 코로나바이러스 감염증의 새 이름은 코로나19이다. 병원체 미상의 폐렴 환자들은 대부분 중국 후베이성 우한시에 위치한 화난수산물시장 방문이력이 있는 것으로 확인되었고 이 시장은 이름과 달리 수산물 뿐 아니라 다양한 가축 및 야생동물 들도 빈번히 거래되는 장소였기에 진원지의 하나로 의심 받고 있다 (8).

중국질병관리본부(CCDC) 연구진은 초기 폐렴 환자 9명에서 얻어낸 기관지 폐포 세척액과 인후부 도찰 (swab) 시료를 사람의 기도상피세포(HAE)에 감염배양하여 바이러스를 분리하는 한편 중합효소연쇄반응법으로 시료 속의 바이러스 유전물질을 검출하였다. HAE 세포에 배양된 바이러스와 기관지폐포 세척액 시료에서 NGS로 염기서열을 결정하고 BLAST로 분석한 결과는 다음과 같았다: 첫째, 완전한 유전체로 읽혀진 8종의 염기서열은 서로 $99.98 \%$ 이상의 상동성을 보임에 따라 이 바이러스가 사람에게로 넘어 온 시점은 아주 최근이라는 점. 둘째, 이미 등록되어 있는 염기서열 중 코로나19와 가장 유사한 염기서열은 박쥐에서 검출되었던 코로나바이러스로서 베타 그룹에 속해 있는 bat-SL-CoVZC45와 bat-SL-CoVZXC21 두 종이며 각각 $87.99 \%$ 및 $87.23 \%$ 의 상동성을 나타내면서도 바이러스 수용체의 역할을 하는 S 단백질은 다른 유전자들에 비해 매우 낮은 상동성(약 $80 \%$ )을 보였다는 점. 그리고 마지막 셋째, 그 동안 심각한 중증폐렴을 일으켰던 SARS-CoV와는 약 $79 \%$, 그리고 MERS-CoV와는 약 $50 \%$ 의 상동성을 갖는다는 점 등으로 요약된다 (8) (Fig. 2).

이와 같은 유전체 비교분석을 바탕으로 추론하면, SARS-CoV-2의 자연숙주는 관박쥐일 확률이 매우 높으며 이 박쥐의 몸에서 지속감염의 형태로 존재하던 여러 종류의 변이주 중 하나가 직접 접촉을 통해 또는 매개동물을 경유하여 사람으로 넘어 왔을 것으로 생각된다. 5400 여 종으로 추산되는 포유동물 중, 종수를 기준으로 $20 \%$ 이상을 차지할 것으로 보이는 박쥐(Chiroptera 목)는 남극 대륙을 제외한 세계 전 지역에 약 4,000 개체 $/ \mathrm{m}^{2}$ 의 밀도로 존재하며 한 무리가 1 백만 개체에 이르기도 한다 (9, 10). 에볼라, 니파, 사스, 메르스 등의 병원체가 기원한 것으로 조사된 박쥐의 몸에서 Adenoviridae와 Herpesviridae를 포함한 8 개 과의 ssDNA- 및 dsDNA바이러스와 Rabdoviridae, Coronaviridae, Paramyxoviridae를 포함한 14 개 과의 dsRNA- 및 ssRNA 바이러스를 비롯하여 Retroviridae 및 Hepadnaviridae 등의 레트로이드 그룹까지 검출된다는 점은 주목되어야 할 것이다 (9).

2002-2003년 전 세계의 사스 대유행 이후 현재까지 Genbank에 등록한 코로나바이러스 중 앞서 언급한 두 종의 bat-SL-CoV 들과 상대적으로 높은 상동성을 나타냈지만 $\mathrm{S}$ 단백질 등을 고려할 때 이들이 직접적인 조상일 가능성은 크기 않다. 같은 맥락 에서, 베타코로나바이러스 중 동일한 SARS-like (SL) coronavirus 종에 속하고 호흡기 외에 소화기 감염이 종종 수반된다는 점 에서 SARS-CoV와 여러 임상 특성을 공유하지만 분자계통학적 측면에서 SARS-CoV-2는 분명하게 분지되는 과정을 겪은 것으로 보인다. 물론 염기서열 유사성이 절반 남짓한 MERS-CoV와는 꽤 오래전에 나뉘어 진화했으리라는 추정이 합리적이다 $(2,6,8)$.

\section{SARS-CoV-2 전파의 역학적 특성과 치사율}

발생 후 불과 3개월 전후인 현 시점에서 집계된 감염확진자의 수를 보면 SARS-CoV-2의 사람 간 전파력이 사스나 메르스 코로나바이러스에 비해 월등히 높다는 사실을 적시하고 있으며 이 바이러스의 감염재생산지수 $\left(R_{0}\right)$ 도 그간의 추정치를 훌쩍 넘기리라는 것을 알 수 있다 $(8,11)$. 따라서 지금 대다수의 관심사는 자연숙주가 박쥐로 추정되는 SARS-CoV-2가 어떤 경로를 타고 사람으로 종간 전파가 이뤄졌는지에 대한 것이다.

SARS-CoV와 마찬가지로 사람의 ACE2 (angiotensin-converting enzyme 2) 단백질에 결합하는 것으로 밝혀진 SARS-CoV-2의 S1-CTD (S1 carboxy terminal; 수용체 결합 영역)와 SARS-CoV의 같은 영역을 비교한 결과와 결합 모델이 보고되었다. 두 영역 사이의 아미노산 서열 상동성은 $76.47 \%$ 에 불과하고 그중 핵심 아미노산 5 개 중 단 1개만 동일하며 그로 인해 결합력을 좌우하는 자유에너지 차가 $28 \mathrm{kcal} / \mathrm{mol}$ 에 달하는 데도 불구하고 오히려 SARS-CoV의 S 단백질보다 SARS-CoV-2의 S 단백질이 $10 ~ 20$ 배의 수용체 친화력을 나타낸다는 연구보고가 뒤이어 나왔다 $(4,12)$. 실제 감염에서 친화력의 차이는 미정이지만 적어도 코로나바이러스 수용체의 구조적 유연성이 한편으로 종간 장벽을 수월하게 뛰어넘는데 기여할 가능성이 적지 않음을 시사한다. 


\section{A} >BetaCoV/Wuhan/IVDC-HB-01/2019|EPI_ISL_402119 (29892 bp)

ORF-lab

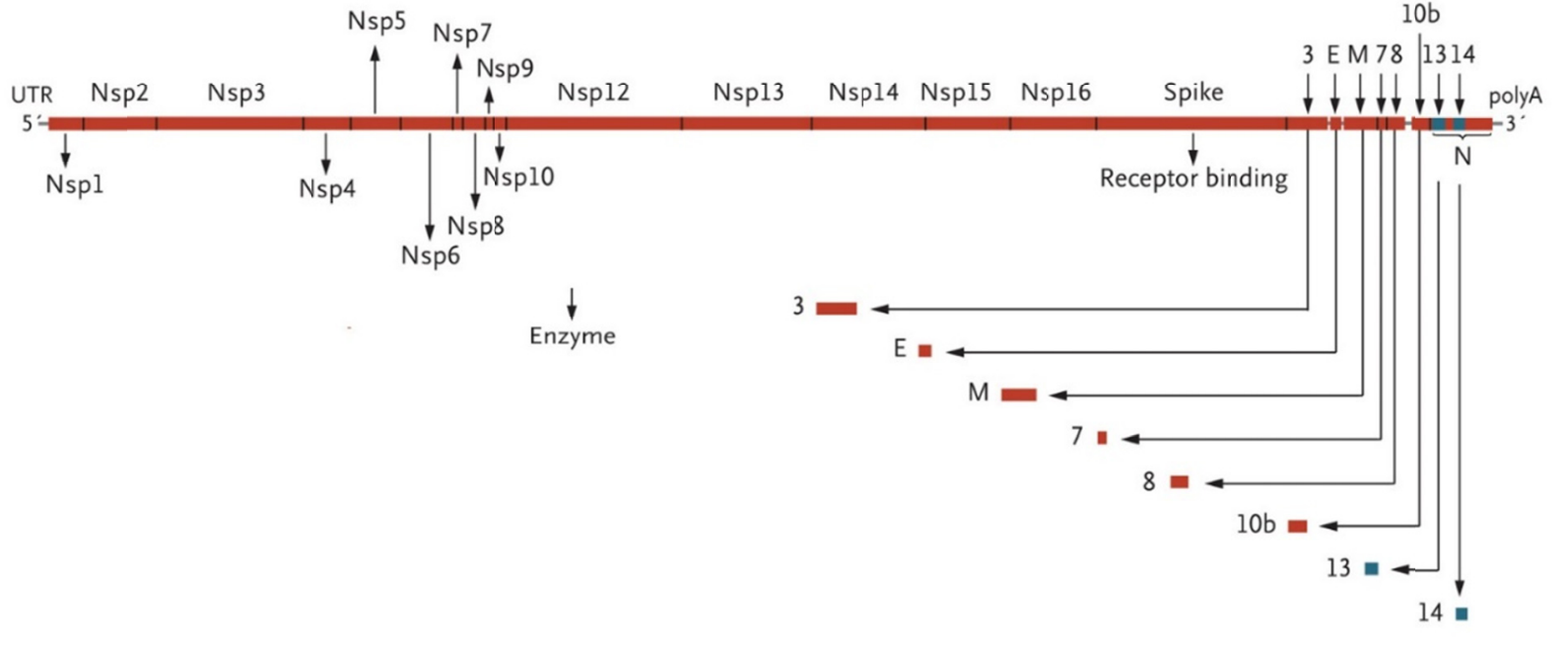

B

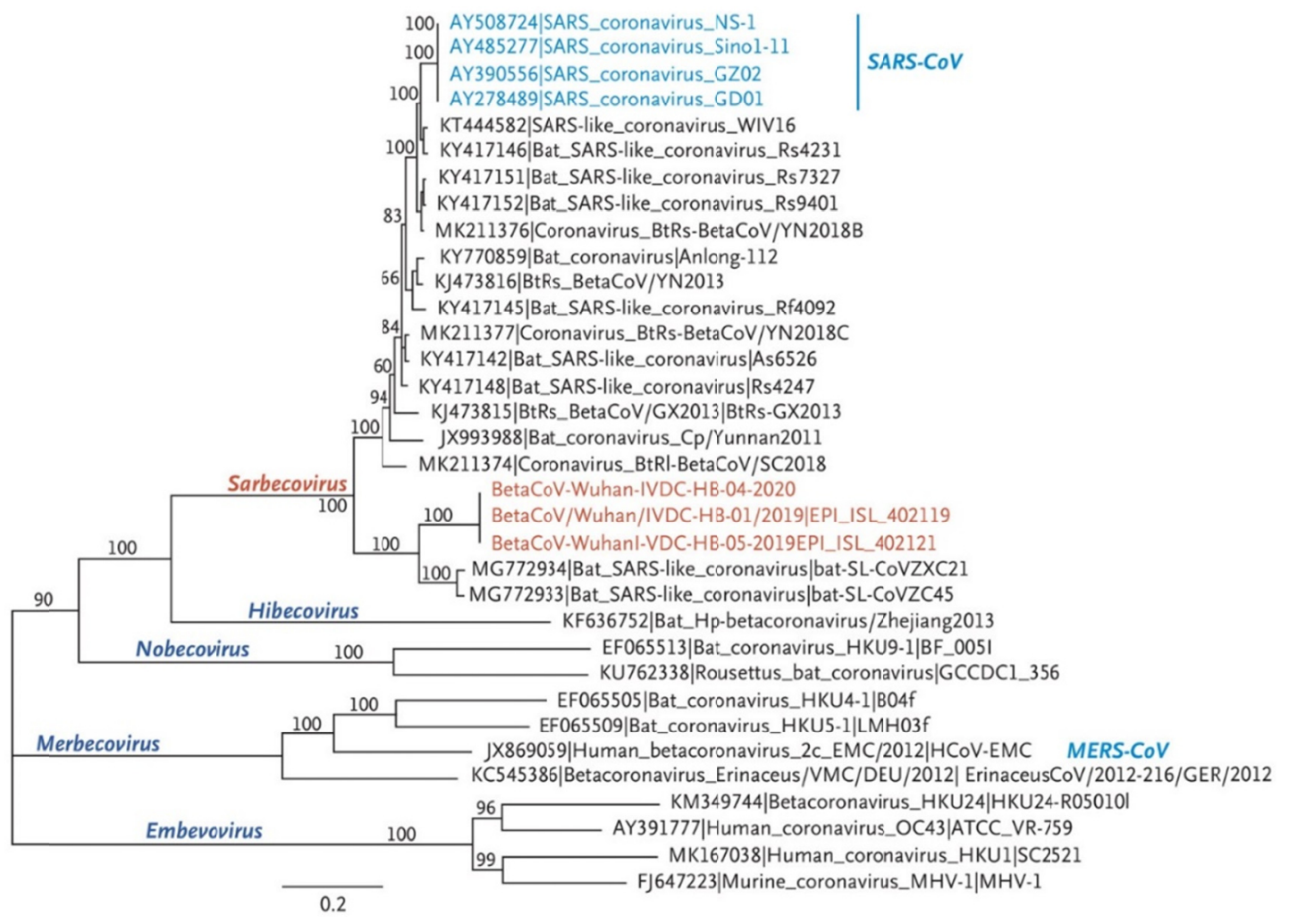

Fig. 2. Schematic of 2019-nCoV and Phylogenetic Analysis of 2019-nCoV and Other Betacoronavirus Genomes. Shown are a schematic of 2019-nCoV (Panel A) and full-length phylogenetic analysis of 2019-nCoV and other betacoronavirus genomes in the Orthocoronavirinae subfamily (Panel B). (Adapted from ref. (19) Zhu et al., A Novel Coronavirus from Patients with Pneumonia in China, 2019 New Engl J Med 2020;382:727-733) 
코로나19 발발 이전, 중국 윈난성 박쥐의 분변에서 얻어낸 베타코로나바이러스(BetaCoV/bat/Yunnan: Bat RaTG13)가 SARSCoV-2의 염기서열과 매우 높은 상동성(>96.2\%)을 나타냈지만 약 1100 여 개의 염기가 다른 것으로 보아 SARS-CoV-2가 박쥐에서 직접적으로 사람으로 넘어오기 보다는 사향고양이나 단봉낙타가 중간에 있었던 SARS-CoV나 MERS-CoV의 사례처럼 다른 숙주종을 거쳤을 가능성과 박쥐와 사람의 생태 사이 간극이 그다지 가깝지 않다는 점들을 고려하여 우연한 기회에 어떤 매개동물에 감염하고 그 동물과 사람이 접촉하면서 인간사회에 출현하는 우회적 종간 전파가 설득력을 얻고 있다 $(5,9,13)$. SARS-CoV-2 확산 초반에 파충류임에도 불구하고 뱀이 매개동물로 잠시 회자된 것이나 특히 천산갑(GD Pangolin-CoV)이 후보 중 하나로 설득력을 얻게 된 것도 같은 맥락이지만 사향고양이 이전에 수많은 포유동물 종이 후보 매개동물로 부침했었다는 점에서 어느 하나로 확정하기는 아직 이르다.

이 모든 과학적 분석자료와 추론을 배경으로 우리에게 가장 뚜렷한 실체는 지금 이 순간에도 우한과 후베이성을 중심으로 코로나 19 는 아직 채 숨죽이지 않았다는 사실과 중국에 인접한 몇몇 국가들에서는 오히려 1차 방역망을 넘어선 지역사회 전파가 뚜렷 하다는 점이다. 사실 바이러스의 전파력은 앞서 소개한 수용체 간 상호작용 이외에도 감염자의 임상적 잠복기나 증상의 경미함 등 여러 요인이 관여한다. 일반적으로 바이러스의 치명적 정도 혹은 병독성은 전파력에 반비례하는 경향이 크다. 어떤 바이러스 감염자의 임상적 잠복기가 짧고 증상이 격렬하며 치사율이 높으면 비감염자와 접촉 가능 기간이 짧아져 그만큼 전파 확률도 낮아진다 (14). 에볼라바이러스에 의한 감염증이 이의 대표적 사례인 반면 에이즈의 병원체인 HIV는 최소 수년에 이르는 매우 긴 잠복기가 이런 경향의 변수로 작용한다 (1). 지금까지 밝혀진 코로나19의 임상적 잠복기는 평균 4 5일이며 최대 14 일 정도의 통계치를 보이고 있으나 최근 14 일을 넘어서는 사례도 낮은 빈도로 보고되고 있다. 게다가 감염자가 발현하는 증상은 발열과 기침을 동반한 인후통, 폐렴에 의한 호흡곤란 등의 의료적 처치가 필요한 사례가 많지만 일반 감기나 가벼운 독감 정도의 증상, 경우에 따라서는 무증상에 그치는 사례도 적지 않아 서로 인지하지 못한 상태에서 바이러스 전파가 이뤄지는 확률이 높아 지역사회 전파 가능성은 더 크다 $(3,11,15)$.

SARS-CoV-2 감염에 의한 사망 사례가 주로 우한과 후베이 성에 집중되어 있고 전 세계적으로 진행 중인 시기에 합리적인 치명률을 상정하기는 어려우나 전반적으로는 3.4\% 내외로 추정하고 있다. 2002 2003년 사이 약 9 개월 간 전 세계 29개국에서 8,000 여 명의 감염환자 중 774 명이 사망했던 사스 유행병은 $9.5 \%$ 이상, 2012 년 중동에서 발원하여 25 개국에서 $36 \%$ 정도의 치사율을 보였던 것에 비하면 상대적으로 낮게 느껴질 수 있으나 $R_{0}$ 가 높아 감염자 수치가 크다면 3 4\% 남짓의 사망률도 매우 큰 희생을 초래한다(16). 한편 이와 같은 치명률은 단지 원인 바이러스의 본질적 병독성에만 의존하는 수치가 아니라는 점을 주목할 필요가 있다. 코로나19의 진원지인 우한과 후베이성 지역 이외의 중국 본토는 상대적으로 치명률이 낮고 상대적으로 확진자 수가 적은 인접국 및 여타 국가에서는 사망자가 없거나 있더라도 소수에 불과하다. 의료기술과 수준이 상대적으로 평준 화되어 있는 국제화 시대에는 신종 병원체에 대한 특별한 치료제나 백신이 없을 경우 해당 국가나 지역의 의료인프라를 활용하는 대증 치료가 주요 처치 방안이기 때문에 환자수 대비 의료시설 및 의료인력, 그리고 지원물자의 원활한 공급여부가 핵심적인 변수로 작용할 것이다. 지난 2015년 우리나라에서 186 명의 감염자가 발생했던 메르스는 중동지역과 달리 $20 \%$ 이내의 치사 율에 그쳤으며 2020년 2월말 현재로 우리나라에서는 3천명에 육박하는 SARS-CoV-2 감염확진자 대비 $0.9 \%$ 정도의 치사율을 보이고 있어 전반적인 의료수준과 인프라의 영향력이 크다는 것을 드러낸다 (17).

감염 의사환자 또는 확진환자의 증상 발현 여부, 동선과 접촉 범위 등에 따라 역학적 판단을 바탕으로 펼쳐지는 격리나 시설 폐쇄 등 보건당국의 방역망은 전염병 통제의 성패를 가르는 1 차적 보루이다. 이 체계가 원활하게 작동하고 각 사안 및 단계에 따른 매뉴얼과 의료적 개입, 그리고 자원이 효과적으로 수행되고 또 지원된다면 감염자의 수가 많고 적음은 부차적 사안이 된다. 그러나 감염자가 소수일 지라도 그 감염이 누구를 통해 어떤 정황에서 이뤄졌는지를 명확히 파악할 수 없다면 1차적 방역망을 넘어선 지역사회 전파로 전환되며 당국의 대응체제에는 전략적 전환이 요구된다. 최근 들어 이웃 일본과 이탈리아, 이란 등의 국가에서 전파경로가 불분명한 감염확진 환자들이 빈번히 나타나고 있음은 지역사회 전파의 뚜렷한 조짐이며 최근 통계로 우리나라의 확진자 중 $50 \%$ 내외는 지역사회 전파에 의한 것으로 나타났다. 최근 국내 방역조치의 단계가 '경계'에서 '심각'으로 바뀌면서 감염자 동선 추적과 격리를 중심으로 한 기존의 대응 방법에서 감염자를 신속하게 발굴하고 신속한 의료 개입으로 중증으로의 이환빈도를 줄이는 전략을 추진하고 있다. 


\section{CONCLUSION}

우한시를 중심으로 한 중국에서 하루 수천 명의 코로나19 환자와 수백 명씩의 사망자가 보고될 즈음 한 학술지에서는 SARSCoV-2의 감염재생산지수, 무증상 전파 여부와 파급력, 병독성, 계통발생적 기원, 유전자 정보 특성, 그리고 항바이러스제 개발 가능성 등을 바이러스 연구자들과 의료진이 풀어야 할 당면한 숙제로 제안했다 (11). 이들 중 적어도 서너 항목은 바이러스 연구자들에 직접적으로 해당할 것으로 보인다. 2002년 사스와 2007년 및 2014년 에볼라 출혈열 유행 이후 많은 연구자들이 박쥐에 지속감염 형태로 존재하는 다양한 동물바이러스를 검출했고 박쥐는 이 바이러스들의 종내 또는 종간 재조합의 터로 기여하게 되기에 신종바이러스의 끊임없는 출현이 예고되었으나 코로나19에 대한 지금 국제사회의 반응은 전혀 예상치 못했음과 다르지 않은 것이 현실이다. 국내에도 30여 종에 이르는 관박쥐가 자생하고 있으며 이들에서도 코로나바이러스를 포함한 여러 종의 바이러스 유전물질이 검출될 것은 자명하지만 환경생태와 동물 및 사람의 감염성 질병을 연결하여 관리하고 연구하는 개념 (One Health)은 극소수 연구자들에 한정되어 있는 것으로 보인다. 21세기에 들면서 기후변화는 예상 단계를 넘어 현실이 되었고 이는 식물의 생태변화로 출발해 동물의 생태변화를 강제하고 동물의 행동 변화는 뜻밖의 감염병 아웃브레이크를 유발한다 (18). 바이러스 연구자들에게 병원체 중심으로 연구하고 대응했던 지난 100 여 년의 표준 전략은 더 이상 모범답안으로 채택되지 못할 공산이 크다. 한편, 원근의 미래 예측에 기반을 두고 국내 연구지원 정책이 표방하는 '선택과 집중'은 예기치 못한 유행병 사태에 부응하기 매우 어려울 수밖에 없다. 특히 지구상 모든 세포성 생명체를 합친 것보다 많은 유전적 다양성을 기록하는 바이러스 연구는 넓은 저변연구의 필수성이 정책적으로 '선택'되어야 할 것이다. 비상사태에서의 저력은 평소의 저변에서 도출된다.

아직도 중국 본토에서는 하루 수 십 명을 넘나드는 사망자가 이어지고 감염확진자 수가 많은 국가들에서도 수백명 이상의 사망 소식이 집계되는지라 코로나19가 한창 진행 중인 사회나 아직 파고를 기대하고 있는 사회 모두에서 시민들의 체감공포는 매우 크다. 진원지에서 시작된 파동의 골은 이웃나라에 마루로 연이어 전달될 수 있기에 이 신종 유행병의 끝이 어디일지는 누구도 낙관 하기 어렵다. WHO는 이미 국제적 공중보건비상사태(PHEIC)의 최고단계 경보를 발령 중이며 2009년 신종플루에 이어 10여 년 만의 대유행을 공표하였다. 국내의 지역사회 전파 상황은 우리에게 새로운 도전과제를 부여하고 있으며 어쩌면 코로나19의 완전한 소멸 대신에 계절성 폐렴으로 우리 곁에 남아 다음 세대들까지도 지속적인 감염 공포에서 벗어나지 못할 수 있다. 인간의 두려움은 맞닥뜨린 위험을 최소화하는데 필요한 마땅한 심리적 방어기제이다. 그럼에도 당면한 위해의 실제는 다양한 요인으로 인해 쉽게 증폭되어 실체적 위해보다 횔씬 높은 체감 위해도를 낳는다는 점에서 당국과 시민 상호 간의 투명하고 진솔한 소통과 협력은 첫째로 주목되어야 할 요인일 것이다. 우리나라와 여러 선진국들은 전문성이 구비된 보건당국과 의료인프라가 잘 갖춰져 있고 바이러스 등 병원체 관련 과학자들도 다수 포진하고 있다. 이런 사회에서 신종 전염병에 대처하는 데에는 과도하게 막연한 두려움에 휩쓸리지 않되 절대 긴장을 놓지 않는 이성적 심리와 전문가의 의견과 가이드를 적극 따라주는 일반 대중의 협조가 가장 중요한 기반이며 지역사회 전파 상황에서는 이런 점들이 특히 절대적이다.

\section{REFERENCES}

1) Master PS, Perlman S. Coronaviridae. In Fields Virology $6^{\text {th }}$ Ed. p.825-58.

2) Cui J, Li F, Shi ZL. Origin and evolution of pathogenic coronaviruses. Nat Rev Microbio/2019;17:181-92.

3) Su S, Wong G, Shi W, Liu J, Lai ACK, Zhou J, et al. Epidemiology, genetic recombination, and pathogenesis of coronaviruses. Trends Microbio/2016:24:490-502.

4) Xu X, Chen P, Wang J, Feng J, Zhou H, Li X, et al. Evolution of the novel coronavirus from the ongoing Wuhan outbreak and modeling of its spike protein for risk of human transmission. Sci China Life Sci 2020;63:457-60.

5) Menachery VD, Yount BL Jr, Debbink K, Agnihothram S, Gralinski LE, Plante JA, et al. A SARS-like cluster of circulating bat coronaviruses shows potential for human emergence. Nat Med 2015;21:1508-13.

6) Gorbalenya AE, Baker SC, Baric RS, de Groot RJ, Drosten C, Gulyaeva AA, et al. Severe acute respiratory syndrome-related coronavirus: the species and its viruses-a statement of the Coronavirus Study Group. BioRxiv 
2020;1-15.

7) WHO. https://www.who.int/emergencies/diseases/novel-coronavirus-2019

8) Lu R, Zhao X, Li J, Niu P, Yang B, Wu H, et al. Genomic characterisation and epidemiology of 2019 novel coronavirus: implications for virus origins and receptor binding. Lancet 2020;395:565-74.

9) Hayman DT. Bats as viral reservoirs. Annu Rev Viro/2016;3:77-99.

10) Luis AD, Hayman DT, O'Shea TJ, Cryan PM, Gilbert AT, Pulliam JR, et al. A comparison of bats and rodents as reservoirs of zoonotic viruses: are bats special? Proc Bio/ Sci 2013;280:20122753.

11) Callaway E, Cyranoski D. What scientists want to know about coronavirus outbreak. Nature (News in focus) 2020; 577:605-7.

12) Wrapp D, Wang N, Corbett KS, Goldsmith JA, Hsieh CL, Abiona O, et al. Cryo-EM structure of the 2019-nCoV spike in the prefusion conformation. Science 2020. pii: eabb2507.

13) Cohen J. Mining coronavirus genomes for clues to the outbreak's origins. 2020 Science.

14) Flint J, Racaniello VR, Rall GF, Skalka AM. Emergence. In Principles of Virology $4^{\text {th }}$ Ed. 2015. p.342-54.

15) Bai $Y$, Yao L, Wei T, Tian F, Jin DY, Chen L, Wang M. Presumed asymptomatic carrier transmission of COVID-19. JAMA 2020.

16) Al-Tawfig JA, Zumla A, Memish ZA. Travel implications of emerging coronaviruses: SARS and MERS-CoV. Trav/ Med Infect Dis 2014;12:422-8.

17) Noh JW, Yoo KB, Kwon YD, Hong JH, Lee Y, Park K. Effect of information disclosure policy on control of infectious disease: MERS-CoV outbreak in South Korea. Int J Environ Res Public Health 2020;17:.Pii:E305.

18) Bagamian KH, Towner JS, Kuenzi AJ, Douglass RJ, Rollin PE, Waller LA, et al. Transmission Ecology of Sin Nombre Hantavirus in Naturally Infected North American Deermouse Populations in Outdoor Enclosures. PLoS One 2012;7: e47731.

19) Zhu N, Zhang D, Wang W, Li X, Yang B, Song J, et al. A novel coronavirus from patients with pneumonia in China, 2019. N Eng/ J Med 2020;382:727-33.

20) Dennehy JJ. Evolutionary ecology of virus emergence. Ann N Y Acad Sci2017:1389:124-46. 